Bosch S., Schmidt M. (2019): Is the post-fossil era necessarily post-capitalistic? - The robustness and capabilities of green capitalism. In: Ecological Economics 161, 270-279. DOI:

https://doi.org/10.1016/j.ecolecon.2019.04.001.

\title{
Is the post-fossil era necessarily post-capitalistic? - The robustness and capabilities of green capitalism
}

\section{Stephan Bosch and Matthias Schmidt}

Our central target is to show that capitalism is not only much more robust to crises than presumed by its critics, but also features promising capabilities with regard to solving the environmental crisis. To elaborate this thesis, we analyse how far capitalism can survive given the end of fossil energy carriers and may maintain its pro- ductivity under the preconditions of a regenerative energy system. In a further step, we demonstrate that crises may actually provide the prerequisites of the economy's transformation towards sustainability. We argue that especially competitive capitalism as analysed by Schumpeter offers excellent preconditions for generating environmental innovations. However, we will also point out the numerous social problems of green infrastructure projects. In the last section, we assume that markets alone will not suffice to concertedly solve the global environmental crisis. Here, political action is needed that pools societal forces with regard to the ecological challenges, hence specifically promoting desirable innovations. The usefulness of state measures is to be judged in correlation to the respective specific national political and economic contexts. A generalised opposition to capitalistic social orders disregards the complexity of these contexts and is at danger of omitting decisive determinants of crisis management.

\section{Introduction}

Ever since the Oil Crises and the rising of the Ecological Movement in the 1970s, academic concern regarding the imminent breakdown of modern society has been accumulating (Meadows et al., 1972; Daly, 1991; Sieferle, 1997; Altvater, 2005; Schwartzman, 2008; Huber, 2009; North, 2010; Kallis et al., 2009; Martinez-Alier, 2012). The key feature of the debate is the energy system, since practically any kind of human activity is dependent on energy, and since economic growth always entails a rise in energy consumption (Martinez-Alier, 1987; Daly, 1995). Human's quest for new energy sources was and is therefore a fundamental one (Sieferle, 2001; Solomon and Krishna, 2011; Rifkin, 2013). At the moment, it expresses itself in the substitution of fossil energy carriers by renewable energies (Resch et al., 2008). One main reason for this transformation lies in the negative accompanying effects of the fossil-nuclear energy system, e.g. climate change and environmental degradation. The usage of fossil energy carriers is also limited by their natural shortage (Meadows et al., 2004). Yet scientists disagree on the question at what point in time the depletion of supplies will actually occur, ultimately compelling a remodeling of the energy system (Bridge, 2010).

Undisputedly, the static reach of crude oil, a resource of high importance for our society, is the lowest among fossil energy carriers (Statista, 2017). Garcia-Olivares and Sole (2015) expect Peak Oil to arrive no later than 2021, entailing the quick exhaustion of fossil fuel reserves within a few decades. How much such prognoses not only nurture left-wing criticism of fossil capitalism, but likewise provide capitalism with the opportunity of depoliticising the environmental crisis by stimulating apocalyptic fears, is described by Swyngedouw (2010). His concern implies the assumption that radical changes within the capitalistic social order will not suffice to guide mankind towards sustainability. However, the European Commission's strategy for the reduction of greenhouse gas emissions does not question the existing socio-material conditions; rather, the Commission speaks of a cost-effective transformation of the electricity sector (EC, 2018). European policy thus makes fossil energy carriers the core point of criticism, not the economic order. In contrast, leftist critics only seemingly target fossil fuels; they actually aim at the economic system: capitalism, which so far has been able to function on a stable foundation formed by fossil energy carriers. According to Huber (2009), capitalism's relationship with nature is essentially characterised by its dependence on fossil energy carriers. Its logic of 
constant growth and accumulation is based solely on the unique characteristics of coal, gas, and oil and cannot be transferred to a regenerative energy system. According to this line of argument, the end of fossil fuels would imply the end of the capitalist system (Altvater, 2007; Huber, 2013; Garcia-Olivares and Sole, 2015;

Kinder, 2016; Buch-Hansen, 2018).

Although McCarthy (2015) as well as Kenis and Lievens (2016) consider it desirable that the rearrangement of the energy system were combined with the rearrangement of the socio-material relationships, they do not only see the energy system's transformation towards renewable energies as sufficient strategy for overcoming the global environmental crisis, but also as a chance for capitalism to prevail. Still, McCarthy (2015) - adopting a Marxist perspective - warns of creating power asymmetries, especially in rural space, where inhabitants are often legally powerless against the regenerative energy systems' high demand for land while being deprived of their livelihood by dispossession (see also Yenneti et al., 2016; Avila, 2018). Harris-White and Harris (2007) emphasise that renewable energies do not only stimulate the development of decentralised structures of supply on a communal level, but could also be embedded in the capitalist logic of market and mass production. Böhm et al. (2012) likewise see the chance of transforming capitalism towards a 'New Green Deal', respectively towards a green capitalism (Brand, 2016), though the authors do not recognise an approach to solving social problems and global disparities therein. Some Marxist oriented environmental researchers therefore strictly object to a 'moderate green capitalism' (Harris, 2010). Moreover, Harriss-White and Harriss (2007) deny the possibility of a thoroughly ecological capitalism, as capitalism always entailed materialistic lavishness as well as a steady increase of entropy. Polanyi (1957) even takes market economy to be the source of the demolition of any social and environmental relationship.

We are hence facing two fundamental dimensions of criticism of capitalist regenerative energy systems; under the latter we subsume any form of renewable energy, energy networks and storages, institutional frame conditions, sociomaterial conditions, as well as governmental, economic, and communal players, and civil society (Gailing et al., 2013; Quaschning, 2014). The first dimension negates the possibility of a green capitalism, comprising the assumption that the capitalist social order, which essentially developed from the socio-material characteristics of fossil fuels, could not be transferred to the socio-material logic of regenerative energy systems. The second dimension does see the possibility of a green capitalism, but rejects it for reasons of social fairness as well as due to the material limits of mass markets, therefore favouring the deployment of regenerative energy systems within a socio-materially thoroughly transformed social framework.

Our central target is to question the following assumptions these two dimensions of criticism are based on:

- The renunciation of fossil energy carriers inevitably leads to a decrease in productivity (cf. Altvater, 2007; Huber, 2009; North, 2010).

- The environmental crisis proves capitalism's failure and lack of viability (cf. Harvey, 2011; Kallis, 2011; Huber, 2013; Buch-Hansen, 2018).

- Innovation is a phenomenon that solely concerns technological issues and is bounded by the limits of human imagination; it is therefore unable to promote a society's sustainability (Harriss-White and Harriss, 2007; Kallis, 2011; McCarthy, 2015).

- The capabilities of green capitalism are strongly limited (cf. Castree, 2010; Böhm et al., 2012; Harris, 2013; McCarthy, 2015; Brand, 2016).

- The differentiation between the distinct forms of capitalist systems is unnecessary, as any form of capitalism jeopardises the implementation of a sustainable social order (cf. Kallis, 2011; Mathews, 2011; Huber, 2013; Kinder, 2016).

The paper is structured as follows: After covering the close, but crisis-laden relationship between fossil energy and capitalism in Section 2, we will investigate the first dimension of criticism in Section 3 and show that the robustness of capitalism to changes in the energy and crude material base is much greater than it is assumed by many studies. We hold the view that the opportunity of space-time compression does not end with the introduction of volatile regenerative energy systems. However, in this context, we will also point out the social problems of large-scale green infrastructure projects. Furthermore, we demonstrate that critical situations do not necessarily herald a breakdown, 
but provide the prerequisites of effectively reorienting the capitalist system to the upcoming societal challenges.

Concerning the second dimension of criticism, Section 4 illustrates how the rejection of green capitalism overlooks promising approaches to surmounting the environmental crisis. On the one hand, we argue that in face of the given narrow time slot as well as the prevailing political strategies, it is more realistic and pragmatic to primarily assess the efficiency of market-oriented solutions. Even though in principle we take sufficiency to have the best effectiveness regarding the solution of ecological and social problems, we still do not count on people's willingness to live in greater moderation within due time. On the other hand, we therefore presume that there are no other suitable economic frame conditions for surmounting the crisis than those offered by the capitalist social order. This perspective is based on the assumption that innovations, which above all emanate from thriving economies (Wangler, 2013), are highly relevant for overcoming the environmental crisis. As growth, innovation, and the development of new industries are to be seen as directly related to the export sector as well as the utilisation of comparative advantages (Bathelt and Glückler, 2012), we therefore also strictly object to the concept of autonomy. Moreover, we take innovation and the aspects of growth, entrepreneurship, and democratic processes of negotiation related to it (cf. Gailing et al., 2013; Walter and Gutscher, 2013; Raven et al., 2016), to be essential for the implementation of regenerative energy systems and social welfare (Iversen, 2005; Nasirov et al., 2017).

Our presumption that innovations occur more likely and more frequently within a capitalist, than in alternative social orders (e.g. Harris, 2013: socialist markets), is derived from Schumpeter's notion of competitive capitalism, which he distinctly sets apart from trustified capitalism. Competitive capitalism is about fertile destructive impulses emanating from enthusiastic entrepreneurs who are ready to take risks, and act solution-oriented. These impulses may revolutionise the economic process: "This process of Creative Destruction is the essential fact about capitalism" (Schumpeter, 2009). Based on Schumpeter's 'theory of economic development' (cf. Herzog and Honneth, 2016; Schumpeter, 1994; Schumpeter, 2009) - which, according to Marques (2008), represents the original idea of innovation-driven capitalism - we analyse capitalism's robustness to the downfall of fossil energy; moreover, we investigate its potential contributions to ecologic sustainability. Yet we want to go beyond Schumpeter's perspective, which fixes on the entrepreneur, and take a closer look at the role of state policy in Section 5. Our argument is that creative entrepreneurs and markets alone will not suffice to specifically and quickly initiate the change of the energy system driven by innovation. We state the thesis that an active role of the state is needed which relies on political continuity when it comes to promoting environmental innovation and creates stable institutional frame conditions. In a last step, we will show that during the deployment of regenerative energy systems, social aspects have hitherto been given too little attention by actors of state and politics and that national objectives were uncoupled from local contexts. To achieve a successful low-carbon transition, these deficits need to be corrected. In principle, this seems possible, as market-economically oriented regenerative energy systems have often been the result of open-minded democratic negotiations. In Section 6, the findings of the study will be summarised.

\section{The crisis of fossil energies and capitalism}

Energy sources are a central element of humankind's materialistic history and elementary changes in the relevance of energy carriers have always led to extensive economic and societal transformations (Bridge et al., 2013). Exemplarily, the drastic increase in productivity during ind ustrialisation cannot be explained without the revolutionary change of the energy system towards fossil fuels (Osterhammel, 2011). Ever since, economic growth is accompanied by an increasing consumption of finite energy resources and non-energetic primary materials (Altvater, 2005). Accordingly, questions of economic development must always be regarded in the context of the energy system, as well as the circulation of energetic and non-energetic crude materials within it (Meadows et al., 2004). Altvater (2007) takes the relationship between humans and nature to be crisis-laden because a limited stock of energy resources within the Earth's thin crust forms the basis of the present economic system. This limitation implied grave consequences for the global ecology. The apparently crisis-laden interrelation of nature and economy is also highlighted in 'Anthropocene or Capitolocene?' edited by Moore (2016), in which the impacts of capitalism are regarded as significant enough to be marked as their own geochronological era. The main point of criticism is capitalism's orientation to industrial scaling and quantitative growth (Mathews, 2011), which likely will end abruptly once Earth's limited capacities will have been depleted by the exponential growth of population and economy (Daly, 1995). Yet not only the finiteness of energy carriers, but also the accumulation of extreme meteorological incidents, 
mass mortality of species, and sea level rise represent impediments of stable economic growth (McCarthy, 2015). The scenarios concerning trends of the world's condition developed by the Club of Rome illustrate that keeping a high wealth level can only be accomplished if a radical change in societal attitude concerning the valuation of growth will take effect (Meadows et al., 2004). Stopping environmental destruction while maintaining the present economic system appears to be impossible, since fossil energy carriers provide globally acting companies with the opportunity to spatially separate production and consumption as well as to externalise the manifold ecological expenses (Chisholm, 1990).

Bridge (2010) rates the heated debates about Peak Oil as ecologically motivated forebodings of a new energy order in which the modern industrial nations are going to free themselves of their dependence on oil. For Neomarxist groups, the end of the age of mineral oil even represents an apocalyptic turn of eras during which nature were going to take vengeance on the ecological arrogance of capitalism. According to Bettini and Karaliotas (2013), the narration of Peak Oil thereby attains a symbolism that reaches far beyond mathematical calculations of the scarcity of fossil energy sources, being extended to a general criticism of a system that is exclusively oriented on growth. McCarthy (2015) sees the chance of a post-fossil capitalism especially in the commodification of wind, sunlight, geothermal heat, and waves. This way, nature would again be introduced into the cycle of capital. Van den Bergh (2011) presumes that this may be a practicable approach, perceiving criticism of market economy and capitalism as too radical and warns of onesidedly problematising growth without simultaneously pointing out realisable alternative ways. He therefore prefers the 'agrowth-concept', which assumes a neutral position on growth, trying to create social as well as ecological sustainability by means of pricing policy, environmental agreements, and education initiatives.

The commodification of nature, however, is rejected by the de-growth movement, as the comparison of the Montreal Protocol, which is based on regulations (ozone) with the Kyoto Protocol based on trade had shown a greater effectiveness of regulative measures (Kallis, 2011). Concerning the market's capabilities, North (2010) additionally speaks of the neoliberal enthusiasts' mindless faith in technology, who were mistakenly convinced that creative destruction is sufficient to face the societal challenges posed by Peak Oil and the climate crisis. Sarkar and Kern (2008) limit the possibilities of the global community's further development to the two options 'eco socialism' or 'barbarism'. This rhetoric stylises capitalism as the image of the enemy: on the one hand, it represents the cause of the global ecological crisis due to the exploitation of natural resources - and for that reason alone were not to be maintained (Daly, 2005) - while on the other hand not offering a suitable social framework for mastering the crisis (Kallis et al., 2009). Hence, the development of a symbiotic economy (Garcia-Olivares and Sole, 2015) rooted beyond obsessive economic growth (Buch-Hansen, 2018) is promoted. Renewable energies were apt to meet these requirements since they can be developed through collaborative bottom- up mechanisms on a communal level, therefore enabling the decentralisation and democratisation of energy supply (Rifkin, 2013). In fact, this may be an option. However, in the following, we want to demonstrate that capitalism is not only very robust to crises, but is also able to contribute to the solution of the environmental crisis.

\section{Robustness of capitalism}

\subsection{Space-time compression}

We will now show that the possibility of increasing productivity does not end with the transition to a regenerative energy system, but only needs to be embedded into new logistic-infrastructural contexts. In this, we contradict Altvater (2007), Huber (2009) and North (2010), who claim that capitalism could expand only on the basis of fossil fuels, since, due to the global transportability of oil, gas, and coal, entrepreneurial actions are no longer bound to the local availability of energy resources, but range globally. Furthermore, the usage of fossil energy carriers is not subject to daily or seasonal fluctuations. Transportability and baseload capacity hence lead to space-time compression (Harvey, 1996), as products can be generated in ever shorter intervals of time. Following this logic, the limitation of the fossil resource basis inevitably brings about the end of the capitalistic system.

It remains undisputed that energy flow within a solar-based energy system is hard to control (Georgescu-Roegen, 1971). Most forms of renewable energies are intermittent sources, whose contribution to the energy mix are subject to the rhythms of sun, wind, precipitation, and tides (Fares, 2015). Adapting energy production to demand, a fundamental prerequisite of continuous economic growth, thus becomes a major challenge. What Altvater (2007), 
Huber (2009) and North (2010) actually do not include in their considerations, are the numerous technological innovations for the stabilisation of regenerative energy systems. After all, with biomass and geothermal power, two energy carriers capable of providing base load are at hand (Matek and Gawell, 2015), which may, in the form of regenerative combined power plants, support the weather-dependent energy sources sun and wind (Palensky and Dietrich, 2011; Ramchurn et al., 2011). The numerous energy storage technologies are also important, albeit only few of these have reached industrial maturity. In principle, mechanical, chemical, electrical, or thermal kinds of storage are being discerned (Hadjipaschalis et al., 2009). Compressed air and pumped storage power plants with efficiency levels of up to $80 \%$ are especially promising (Anagnostopoulos and Papantonis, 2008). Research is also conducted on the conversion of surplus regenerative power into methane or hydrogen (Jensen et al., 2007), by which the bidirectional operation of the power and gas network is made possible, allowing for transportability as well as baseload capacity within large spatial units.

Space-time availability may also be augmented by the development and capacity expansion of high-voltage transmission lines (Walter and Bosch, 2013). Harriss-White and Harriss (2007) have pointed out at an early point, that the existent grids, having been developed following a monopolistic logic, are outdated and incapable of integrating decentrally-produced electricity with strong fluctuations. These deficits, however, are successively being corrected. E.g., Germany's South, which is poor in wind but strong in terms of industry is being provided with direct access to the big wind energy off-shore potentials in the North as well as to the storage power plants in Scandinavia (cf. Fig. 1). The possibilities of intercontinental power transport from regenerative sources have been thoroughly investigated by DLR (2006) and Grossmann et al. (2014). 


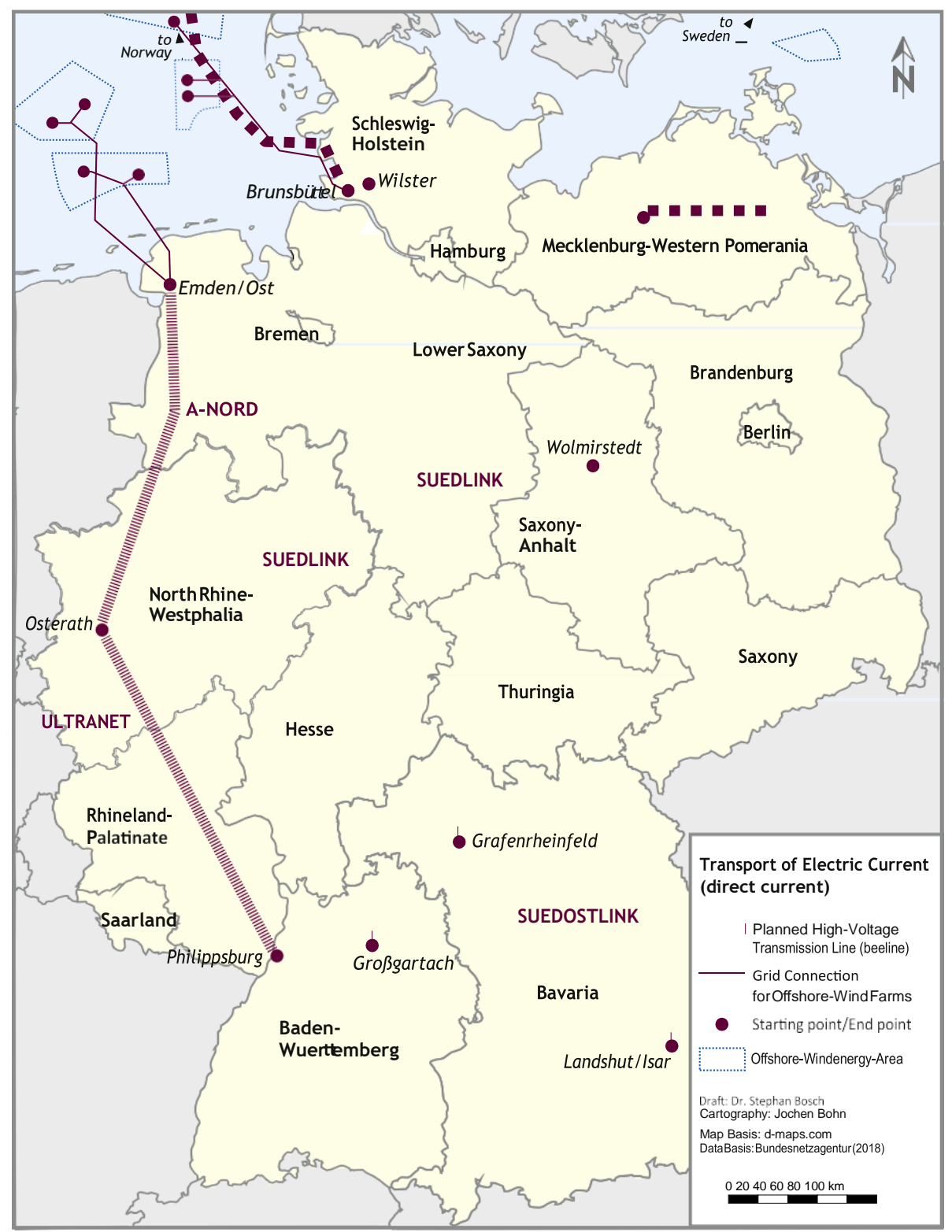

Fig. 1. Deployment of direct current high voltage transmission in Germany - space-time compression in regenerative energy systems.

Both energy storage and the development of the power grid thus will successively reverse the present space-time limitations of regenerative energy systems. The two domains, however, are not isolated from one another, but are coordinated via smart grids. Solomon and Krishna (2011) emphasise that smart grids are superbly suitable for the implementation of market-based approaches, so that an innovation- driven mass market for energy efficiency technologies could be anticipated. Smart grids also provide the possibility of no longer designing the mass production of renewable energy technologies on a fossil basis, but by the usage of renewable energy. While the production of the first generation of regenerative technologies was based on fossil energy, in future, the possibilities of energy storage, the almost unlimited energy potential of a solar-based economy, and the combination of both aspects through smart grids will ensure the flexible provision of regenerative energy at every production site without limits of time. Yet in order to optimise the flows of energy and material in smart grids, concepts of closed crude material cycles are needed, which, in the sense of the cradle-to-cradle approach (cf. Section 4), allow the reintroduction of used materials (e.g. old wind power plants made of renewable resources) to the biosphere. Thus, the problem of externalisation of ecological costs can be minimised.

Summing up, the increase of productivity and stable economic growth within regenerative energy systems seems 
possible. Still, it remains to be emphasised that large-scale energy projects also entail negative social consequences. E.g., Yenneti et al. (2016) have shown that the Charanka solar park in Gujarat, India, was erected on areas that the local population's livelihood had depended on for decades. The refuse of access to these areas, as well as the inhabitants' successive dispossession through state measures thus are direct results of the Indian economy's ecological modernisation (Levien, 2013). In this context, Baka (2013) speaks of "energy dispossessions", a phenomenon which has also been observed with large-scale wind energy parks (Avila, 2018; Cowell, 2010). The sociomaterial impact of economic modernisation on the local population, whose lives strongly depend on agricultural land use, are often insufficiently respected (Yenneti et al., 2016), so that the dubious impression was given that environmental protection and economic growth based on efficient technologies, competition, and state measures could go with one another without social side effects. Remarkably, the controversial energy mega-projects especially in the global South, are not the cause of the development of new power asymmetries and conflicts, but rather reproduce and harden long-standing social disparities and injustices (Avila, 2018). According to Bradley and Hedrén (2014), a low-carbon transition hence misses its aims if it is only about modernising the energy system without likewise transforming the underlying social structures.

\subsection{Crisis as an element of capitalist social order}

We hold the view that the occurrence of crises in capitalism is not due to it being an ailing, doomed economic order; nor is it a proof of capitalism's ineptitude for meeting ecological challenges. Instead, we deem that crisis is a fundamental element of the capitalist social order that actually provides a chance for readjusting economic processes.

Harvey (2011) explains that anything blocking the circulation and accumulation of capital may pose a threat to the capitalist system and induce a fundamental crisis. The finiteness of fossil fuels is a crisis of this kind (McCarthy, 2015). Altvater (2007) is convinced that capitalism will not be able to overcome this crisis; therefore, future technologic progress had to be embedded in a non-fossil, non-capitalist framework. Kallis (2011) also emphasises that the approach to a steady state (cf. Daly, 1991, 2005) will transform the institutional preconditions of property, work, banking, and distribution to such an extent that in the end, it will be impossible to still identify them as capitalistic.

With regard to Kallis' doubts concerning the institutional robustness of capitalism, Schumpeter points out that precisely the ups and downs of industrial development, which are the outcomes of successful innovations' intensifying competition, enable progress (Herzog and Honneth, 2016). As crises therefore represent an immanent part of the capitalist system, an environmental and resources-related crisis caused by the capitalistic process does not provide sufficient evidence to suggest a possible downfall of the capitalistic social order. The crisis might even be taken as proof of an economic cycle, if it is regarded as a period of depression between the dwindling fossil and the emerging regenerative age. Böhm et al. (2012) and McCarthy (2015) confirm that capitalism is capable of overcoming even fundamental crises, actually using these as starting points of its further expansion. Concerning the environmental crisis, Harriss-White and Harriss (2007) also concede that the deployment of renewable energies holds the potential of founding a new form of capitalism that is characterised by a much lower degree of materialistic lavishness. Bettini and Karaliotas (2013) emphasise that from a neo-liberal point of view, the accusation of capitalism bringing about a resources-related and environmental crisis does not at all provoke self-doubts. Rather, it caused the profitable marketing of adequate approaches to solutions in the field of resource depletion and environmental impacts to move into economic focus. Even Altvater (2007) points out that the externalised effects of production and consumption on nature become relevant for companies once they jeopardise profitability and accumulation. In that case, environmental problems and their solutions can actually be made part of capitalist logic. Solomon and Krishna (2011) are convinced that in order to solve the environmental crisis, it were not even necessary to achieve further technologic breakthroughs, as the technologies needed for the remodeling of society towards energy efficiency were already mature and cost-efficient.

Even if capitalism might be sufficiently robust, Kallis (2011) still takes the crisis as a chance to break up obstructive social and political lock-ins that have hitherto seemed unalterable and have lead into the crisis. Yet he does not regard the ability of social and political transformation to be inherent in the traits of market, but as a characteristic of a social order orientated towards degrowth. Certainly, Kallis is right in saying that the market is hard to control, making a concerted transformation towards sustainability difficult. Still his criticism only refers to that form of capitalism which

Schumpeter characterised as trustified capitalism and which does lead to ecologically problematic lock-in effects. The 
criticism cannot, however, be applied to competitive capitalism, which generates those basic innovations giving rise to the revolutionary crises described as so fertile by Kallis (2011). Thus, an opportunity is provided for alternative social conditions to be brought about - but within the capitalist social order - and for substantiating these new conditions through further innovations. Innovations may emerge outside of competition and market economy, but will then lack the required frequency and force, as growth represents the most important incentive of innovation (Wangler, 2013). On the other hand, a continuous process of innovation again leads to growth, which may revolutionise the present social conditions, as Schumpeter states (Herzog and Honneth, 2016). Thereby, a new combination of the given means of production within new sites of production emerges, generating new goods, methods, and markets. Productive resources are applied to hitherto untested usages while being withdrawn from those usages they served before (Geels, 2011). What Kallis (2011) terms technological optimism with regard to the ecological innovative power of capitalism, is therefore technological realism in the context of Schumpeter's competitive capitalism.

Without doubt, innovative boosts on the part of already established

companies are also conceivable and may give rise to the possibility of maintaining trustified capitalism with its ecologically precarious structures. An example hereof is the innovation 'Carbon Dioxide Capture and Storage', by which the ecological impact of the emission intensive electrical conversion of coal is being reduced (Benson and Orr, 2008). Technological progress may hence stabilise the existent system of economy and policy that is accountable for the environmental crisis (Bettini and Karaliotas, 2013). In Schumpeter's view, however, the decisive economic order is competitive capitalism, which is characterised by the aggressive economic demeanour of new, innovative enterprises economically challenging the establishment (Herzog and Honneth, 2016). The start-ups of new companies, which are inseparably connected with the processes of innovation, withdraw production goods from the present capitalist system by underbidding, disturbing the former economic balance that is so destructive for nature. Competition is therefore essential for overcoming the environmental crisis. In that respect, the concept of 'solidary economics' and its precept of surmounting the allegedly ruthless principle of competition and emancipating oneself from the logic of the markets (Embshoff and Giegold, 2008), is counterproductive, as the renunciation of competition impedes the breakup of crusted economic structures, which thus continue to harm the environment. After all, the big energy providers' strategy was and is to hold on to the fossil-nuclear power plant pool for as long as possible, suppressing alternative concepts of energy supply (Gawel et al., 2012). A radical transformation of the energy system therefore cannot emerge from the existent structures, as Schumpeter assesses (Herzog and Honneth, 2016). Instead, innovative processes emerge outside of the old major companies until proceeding to attack the incumbent regime through the rededication of means of production (Geels, 2011). Innovative marketing strategies of small and middle scale businesses supplanting cumbersome large companies play an essential part especially in the field of renewable energies (Walsh, 2012). In this, competition is a decisive element that cannot easily be superseded.

\section{Capabilities of green capitalism}

A competitive green capitalism develops great creativity by its high rate of innovation, which may also reinvent the relationship between humans and nature. We now want to exemplify how this might be brought about.

Schumpeter holds the view that innovation is the result of the capitalistic entrepreneurial spirit, not the other way round (Herzog and Honneth, 2016). Technological and social progress hence are no independent variables materialising out of thin air, but arise from the logic of the capitalist process. Meadows et al. (2004) accept that innovations may relocate the limits of growth, making it possible to maintain the living standard by continuously reducing the consumption of crude materials and energy. However, one of the energy system's prevailing deficits is that depleted or not yet tapped resources are being (re-)obtained based on non-regenerative energy (Schwartzman, 2008), causing capitalistic production to be increasingly energetically inefficient (Murphy and Hall, 2011). Overcoming the energy crisis hence calls for the consideration of thermodynamic principles (Georgescu- Roegen, 1971, 1986; Martinez-Alier, 1987). Harriss-White and Harriss (2007) see the deployment of renewable energies as a possibility of limiting the creation of entropy. Kaberger and Mansson (2001) have shown that innovative resources-saving material cycles may be possible and economical if they are based on the usage of the inexhaustible energy of irradiance. What is promising about this approach is that, due to research and development, the utilisation of solar energy becomes more and more efficient and lucrative (Schmid, 2016). Moreover, its inexhaustible potential allows for the exploitation of material resources even from deposits with extremely low crude material density. On a local level, the utilisation 
of solar energy may actually lead to a reduction of entropy (Ebeling et al., 1998; Kranert and Cord-Landwehr, 2010), as it is the case with the usage of waste heat of solar thermal power plants for the desalination of sea water (DLR, 2007). The integration of these capacities into smart grids and the associated remodeling of every production process to purely regenerative sources have been detailed in Section 3.

We further argue that innovation surpasses conceivability. Even Harris (2010) sees a particularly high potential in unpredictable technological innovations to break through economic routine, thus encouraging further entrepreneurs in issuing their own innovations. Capitalism might thereby be provided with the chance to reduce its ecological exploitation. But innovation exceeds strictly technological aspects and may as well comprise social and institutional aspects (Arentsen and Bellekom, 2014). E.g., in the mobility sector, whose pollutant emissions have significantly contributed to the environmental crisis, innovations have led to new features of cargo and passenger transportation. This is illustrated by the example of car sharing as an innovative life style (Prettenthaler and Steininger, 1999) or bicyclesharing schemes in urban areas (Midgley, 2011). Another representative case is the history of the ozone hole, which Meadows et al. (2004) describe as a history of civil success regarding the correction of a severe overshoot. Quite in the sense of Schumpeter, Meadows et al. (2004) name the 'industry's creative heads' as the crucial problem-solving determinant. Through the three innovative boosts 'better insulation', 'reduced toxic substitute materials', and 'emission-free alternative substances', it will be possible to rebuild the original density of the ozone layer by the mid21st century. Remarkably, this is realised without abandoning the existent economic system.

Furthermore, we argue that it is realistic to assume growth-oriented,

competitive markets in the future, rather than socio-material conditions beyond them, which, as stated by Van den Bergh (2011) are completely uncertain as of now (e.g. Harris, 2013: socialist markets). We therefore hold the view that it is more pragmatic to design future mass markets in an eco-friendly way.

Kallis (2011) rejects the possibility that the wonder of a dematerialised economy might occur, as improvements of efficiency were overcompensated by growing consumption. While dematerialisation may be tantamount to a wonder, researchers still do put effort into adjusting the materialised economy to ecological compatibility. One aspect is the thorough redefinition of nature protection, because nowadays, nature protection is reduced to the attempt of limiting the harmfulness of processes and products (Mulhall and Braungart, 2010). However, due to the potential creation of new mass markets for more eco-friendly and efficient processes or products, this strategy holds the danger of actually augmenting unwanted effects through rebound effects. In this regard, Alcott (2005) points to the Jevon's Paradox which says it is a great error to think that technologic innovations were going to reduce the consumption of resources. Polimeni et al. (2015) name the example of the Green Revolution: the remarkable increase of food production's area efficiency was not at all able to abate the problems of hunger and area consumption, as consequently, the population greatly increased. Likewise, a mass market of efficient and eco-friendly products would again lead to a massive amount of poison and waste, with disposed crude materials hardly being recycled. The ecological costs then would have to be externalised, which Sturm and Vogt (2011) regard as strong evidence of the failure of the market.

The core problem hence lies in the fact that products are being produced exclusively for the technosphere (McDonough and Braungart, 2013). E.g., copper is almost universally applicable to and beneficial for technological systems, while in biological systems, this material is extremely poisonous. Thus, the aim must be to design products in a way that makes them equally usable in biosphere, i.e. subsequent to their technical usage. This calls for the development of a combined management of nutrients for techno- and biosphere. Human ways of living, the processes and products they are based on, may thereby be employed for the benefit of nature.

The focus must therefore be put on those innovations that break up the present paradigm of environmental protection by realising products that create a useful material connection between technoand biosphere. An example of this kind of creative destruction is the Austrian company Gugler, the first print shop worldwide that produces printing products free from harmful ingredients and exclusively with substances that can be biologically recycled (Gugler $\mathrm{GmbH}$, 2018). E.g., the accruing sludge is returned to biosphere and the ash of burned printing products can be reused as a fertilizer. These conditions provide the possibility of designing economic activities to be ecologically compatible despite a high resource throughput.

\section{The role of state and policy}

\subsection{Managed transitions}


We think that in principle, the market has the means to surmount the environmental crisis, yet it is hardly capable of assuring the concerted application of these means with regard to the pending societal challenges. Hence we concur with Kallis' (2011) assessment that deregulated markets are not fit for a gradual approach to a sustainable society. Even Schumpeter denies that the capitalistic process is suitable for the strategy of a process of continuous approximation (Herzog and Honneth, 2016) - such as Meadows et al. (2004) demand it of the approximation to the limits carrying capacity. Innovations leading to a radical change in the established bases of economic calculation rather occur discontinuously (Schumpeter, 1994), which makes them too unpredictable for overcoming the environmental crisis. In concordance with Wangler (2013), we assume that ere innovative processes are able to focus explicitly on surmounting a specific kind of crisis, a demand for the respective goods and products must exist beforehand and must be augmented by governmental policy. We therefore argue that market needs an institutional framework within which policy is able to expediently organise innovation. With regard to this, Solomon and Krishna (2011) speak of 'managed transitions'.

That the market alone is inapt becomes apparent in the market-based tendering procedures for renewable energies. Harriss-White and Harriss (2007) emphasise that this strategy has permanently undershot the targeted aims of deployment. In this respect, McCarthy (2015) explains that powerful actors of the capitalist system are not at all interested in a transformation of the energy system towards renewable energies. Stenzel and Frenzel (2008) also state that despite parading green rhetoric, the big energy suppliers exert obstinate resistance. How far this resistance can be broken depends- on the specific national political and economic contexts that influence the development of regenerative energy systems (Ćetković and Buzogány, 2016). However, the authors do not assume contexts other than that of market economy; rather, comparing several forms of capitalism, they take one distinct manifestation of market economy to be a suitable approach to crisis management. In contrast, Kallis (2011) understands any form of capitalism as an institutional compound whose supreme aim is the maintenance of growth and accumulation. McCarthy (2015) supports this thesis and claims that in the context of the environmental crisis, any form of capitalist social order is primarily interested in its own salvation, but not in a societal transformation towards sustainability. Even the political players' commitment to nature protection is mainly about expediently repositioning one's own party in political competition (Harriss-White and Harriss, 2007).

However, our view is that a generalised objection to any form of capitalist social order would disregard the subtle differences between the various manifestations of capitalism, leaving potentials of a competent political organisation for the solution of the environmental crisis unused. We now want to illustrate these differences.

Ćetković and Buzogány (2016) show that liberal market economies distinguish themselves by fierce competition. They are oriented to economic criteria, which leads to them bringing forth groundbreaking innovations in irregular intervals. This means that while a radical reorganisation of the regime in the Schumpeterian sense can be expected, its time and course are not steerable (Geels, 2011). Within coordinative market economies, as Ćetković and Buzogány (2016) state, innovative processes take place gradually and continuously. Here, progress is being subordinated by the state to a long-term development based on research. An example hereof is the transformation of the energy system in Brazil organised by the state in the aftermath of the oil price shock. Manifold steps taken have contributed to increasing the national production and consumption of bioethanol. The government put an emphasis on the promotion of research and innovation in the ethanol industry, which paved the way for Brazil to become world leader in the sector of ethanol technology (Solomon and Krishna, 2011). In Germany, the state likewise made a point of providing comprehensive and stable support for the energy system (Stenzel and Frenzel, 2008). E.g., technology specific feed-in tariffs set above the market price were guaranteed over a 20-year period (Kungl, 2015). Moreover, numerous projects concerning renewable energies, in which enterprises as well as research institutions participated, were promoted (Lauber and Jacobsson, 2016).

These stable frame conditions facilitate the access to credits and loans for investors (Ćetković and Buzogány, 2016). Wangler (2013) is convinced that due to the high production cost of renewable energies as well as the monopolistic market structures of conventional energy supply, the spreading of green technologies in Germany was possible only due to the intervention by the state. According to the author's analysis, the politically induced stimulation of demand for green technologies and the associated effect of a growing market were able to significantly increase entrepreneurial activities in the regenerative sector as well as the innovation rate. This is congruent with the assessment of Solomon 
and Krishna (2011), who say that governmental support of innovation may also be carried out indirectly by promoting and facilitating the consumption of the respective products.

Harriss-White and Harriss (2007) take governmental aid for the consumption of regenerative electric power to be only a compensation for the markets' failure to implement a regenerative energy system. We, however, argue that a failed solo on the part of the market must not necessarily imply a complete abstinence from competition, but that the capabilities of market can be specifically combined with the help of state control. For instance, England's policy had for a long time assumed a liberal attitude, putting the focus on a technology-neutral, cost efficient deployment of renewable energies. As a result, the deployment was subject only to the mechanisms of the market, which left no chance for immature technologies or smaller companies (Stenzel and Frenzel, 2008). This form of capitalism inhibited the development of a national market for renewable energies. According to Kallis (2011), the inhibition consists in the big, powerful companies that are not interested in abandoning the growth-oriented conditions so beneficial for them. Establishing a sustainable societal system could - from his point of view - not be achieved within the institutional framework of capitalism. But in fact, the coupling of market and state, i.e. the implementation of institutional and political frame conditions similar to the German coordinated market economy (e.g. feed-in tariffs guaranteed by the state, state grants for energy projects, condensation of institution, the governmental Green Investment Bank) succeeded in attaining industrial growth and high rates of deployment in England's regenerative energy sector (Ćetković and Buzogány, 2016).

Jänicke (2007) holds the view that the transfer of successful political regulations is an essential prerequisite of innovation, quite in the sense of regulative capitalism. However, Ćetković and Buzogány (2016) point out the limited transferability of political and institutional frame conditions. E.g., Harriss-White and Harriss (2007) emphasise that the development of regenerative energy systems in England was for too long under the responsibility of numerous, partially conflicting ministries and was insufficiently coordinated. This gap was made use of by representatives of the industry who thus exerted significant influence on policy concerning the energy sector, which led to an entanglement of energy policy and the interests of capital. Remarkably, it was precisely this kind of political entanglement, which represented a decisive factor of success during the transformation of the French energy system from oil to nuclear power (Solomon and Krishna, 2011). But irrespective hereof, the differences between the English and the German regenerative energy system must be attributed especially to specific national political and economic contexts. For example, the advantage of the German Energiewende is - among other factors - the result of a much stronger industrial base, which provided Germany with the possibility of establishing its major engineering tradition in the new energy sector (Ćetković and Buzogány, 2016). Further factors of success are the more stable governmental support for industry, vocational training oriented towards a green energy sector, as well as the institutional embeddedness of negotiation processes in regional and local structures. Not least, the energy transition's organisation by bottom-up processes has led to high acceptance (Gailing et al., 2013; Yildiz et al., 2015), making it possible for industrial growth and innovation to occur continuously.

After these national examples, we want to identify the required frame conditions for a successful green capitalism. According to Meadows et al. (2004), the population would need to be better educated in terms of environment, the financial risk of developing new technologies would need to be absorbed by the state, and institutions for the development and expansion of new technologies would need to be created. Moreover, the organisational abilities of state and economy were needed to focus on society's crucial challenges. Solomon and Krishna (2011) explain that the transformation of energy systems required three prerequisites. One of these is basic innovation on the part of niche markets (cf. Geels, 2011; Raven et al., 2016) protected and promoted by governmental institutions. Furthermore, a specific sociotechnical regime with a network of players and social groups is needed, within which a collective value system and coordinated codes of action are established. Finally, it is crucial what macro-economic context innovations and networks are embedded in and what cultural and political roots they are fed by. In the sense of an 'Energy Keynesianism', McCarthy (2015) sees a big conceptional potential on the part of the state if it comes to developing regenerative energy systems. Essential fields of governmental action, according to McCarthy, consist in the tapping of national energy potentials, in the reduction of obstacles for investment, and in the international cooperation concerning energy policy. In view of the immense financial expenditures of the energy system's transformation, he also points to the importance of financial capital that had to provide the big investment sums for the development of climate-friendly infrastructures. A similar view is expressed by Ćetković and Buzogány (2016): a targeted 
governmental energy policy on the one hand comprised the development of a national market for the exploitation of the regenerative energy potential, while on the other hand taking measures that promote the regenerative energy sector's innovative strength, create jobs, and reinforce the industry's international contestability. Also, the acceptance of regenerative energy systems depends on the state's ability of guaranteeing social participation in the form of having a say and a monetary share.

In sum, it can be stated that the market must be accompanied by governmental policy. The energy transition in Germany is an example hereof, as the state significantly contributed to increasing the rate of innovation within the regenerative energy sector by launching the Renewable Energies Act (Kungl, 2015). After all, Germany holds the highest number of technologic patents in the field of solar and wind energy within the European Union (Ćetković and Buzogány, 2016). Yet despite this success, the German energy system is presently being reoriented towards marketeconomy. This turnabout is caused by the fact that economic efficiency of feed-in tariffs is being estimated as insufficient (Johnstone et al., 2010). This holds the danger of weakening the incentives for the deployment of renewable energies. Even private investors in the field of renewable energies are, for reasons of security of investment, very interested in the political framework not vanishing completely (Bürer and Wüstenhagen, 2009). Ćetković and Buzogány (2016) therefore recommend not putting the focus solely on cost efficiency and short-term developments, but creating political and social frame conditions apart from the market that generate industrial growth and innovation, enable the citizens' participation on a broad basis, and help evolve the specific comparative advantages of the respective countries.

\subsection{Consideration of social factors}

In the context of the energy transition's implementation by spatial planning, the narrative of the aesthetic landscape that needs to be protected has evolved, which harshly contrasts with the technified energy landscapes (Van d. Horst, 2007). Schöbel (2012) criticises that this perspective declassifies energy landscapes as non-landscapes. Cowell (2010) even speaks of the marginalisation of industrialised, burdened spaces, which, being classed as profane regions in a hierarchy of landscapes, have to take on the bigger part of the deployment of renewable energies. Yet it has never been resolved what landscapes are to be categorised as worthy of protection and what energetic land uses are to be banned from them in consequence (Palmas et al., 2015). Moreover, the fact is omitted that landscape is culturally relevant for any population in any region, regardless of whether it is beautiful, ordinary, or unattractive (Blaschke et al., 2013). Thus, the question arises how these spatial attributions of relevance were brought about and what social consequences they entail.

Harvey (1996) has pointed out that arbitrary spatial categorisations are often the result of a market-economic, capitalistic logic, in which a few powerful actors control localised resources. Ostensibly, the application of elaborate Geographic Information Systems (GIS) gives the impression that social parameters were meticulously registered. In fact, however, the social dimensions of planning are strictly bounded by political frame conditions that aim at providing the means of remote spatial management. Only this kind of generalisation makes spatial planning socially calculable (Murdoch, 2000). Liljenfeldt (2015) found that in Finland, Norway, and Sweden, spatial planning's possibilities of intervention have been strongly limited for the benefit of more efficient top-down procedures in order to facilitate the attainment of the energy transition's aims. This form of spatial-technical planning, which may, according to the given political guidelines, both integrate or ignore the local contexts, is the powerbase of superordinated energy planning (Demeritt, 2001). The extensive maps produced by these processes visually represent this power: they substantiate the guidelines and aims of energy policy, reducing the subspaces' heterogeneity to controllable categories. Cowell (2010) speaks of the phenomenon of 'foreshadowed search ares'.

To this end, social sciences are often instrumentalised in order to

help break down social barriers for energy-political ambitions (Shove, 1998). This does not mean that policy ascribes no importance whatsoever to social questions. However, social aspects are often manipulated according to the respective interests (Bulkeley et al., 2005) and local contexts are being uncoupled from national aims (Cowell, 2010). But reciprocity between superordinate energy policy and its local contexts is essential, as opposition to renewable energies is recruited from the local population (Van d. Horst, 2007). Zoellner et al. (2008) criticise that energy research for too long has one-sidedly centered on technical aspects of the energy transition, causing social matters to be ousted from focus. This has influenced planning practice and has provoked protests in many places (Aitken, 2010). Especially 
the deficient academic reflection of quantitative guidelines for the deployment or renewable energies led to local opposition's deeper motives being insufficiently appreciated. Scientific problem statements and aims exclusively focused on the question how to accord with energy policy's quantitative guidelines despite decreased acceptance. Ellis et al. (2007) characterise this as an ideologically charged pro-energy attitude that suppresses alternative perspectives. Even the right of participation must be regarded critically if it only serves the cosmetic purpose of legitimising decisions that have been made beforehand (Hildyard et al., 2001). Devine-Wright (2005) therefore recommends considering social distances, which are to be understood as a gauge of fairness.

Literature does indicate that the deployment of renewable energies is often conflictive and can be the result of unfair structures. Yet the foiling of numerous projects especially in the Western market economies also shows that the energy transitions permit vital democratic, open and unbiased negotiation processes taking all societal interests into account (nature protection, preservation of monuments and local history, industry, etc.) (Walter and Gutscher, 2013; Raven et al., 2016). In economic systems oriented to socialistic principles and/or principles of planned economy, this kind of vitality and controversy is not nearly given (Andrews-Speed, 2012), as the concerns of single citizens are not taken into consideration and projects are often enforced against any opposition. The market-economic energy transitions have not least unlocked a great potential of civic engagement (Gailing et al., 2013), so that energy consumers are no longer unilaterally dependent on the big energy companies, but may themselves become energy producers and partake in the development of regenerative energy systems (Yildiz et al., 2015).

\section{Conclusion}

In this paper, we argued that capitalism is not only much more robust than presumed by its critics, but moreover features promising capabilities with regard to solving the environmental crisis.

At the beginning, we elucidated that capitalism is able to prevail even given the end of fossil energy carriers and to maintain its productivity also within a regenerative energy system. Innovative concepts of storage, direct current transmission, and smart grids play a core role herein. Moreover, we were able to show that crisis is an essential element of the capitalist social order, with critical situations even being able to provide the necessary preconditions for the economy's transformation towards sustainability. Innovation is an essential ingredient of this process. We argued that precisely the preconditions given in competitive capitalism generate innovations. Therefore, in our view, the decisive social advantage of a competition-oriented capitalist system is this: as expressed by Schumpeter's concept of creative destruction, it offers maximum incentive for entrepreneurial initiatives. According to the theory of economic development, this incentive cannot be given within the socialist markets or degrowth-oriented societies favoured, but not more specifically detailed, by Harris (2013) and Kallis (2011). Yet this stimulus is crucial as it is accompanied by greater innovational strength, thus providing more auspicious preconditions for groundbreaking innovations, e.g. regarding aspects of technology, education, vocational training, research, social infrastructure, medicine, and nature protection (Schumpeter, 1994; Iversen, 2005; Wangler, 2013). However, we again want to point out the numerous social problems of the deployment of renewable energies (e.g. Aitken, 2010), especially concerning large-scale infrastructure projects (e.g. Avila, 2018).

In the context of competitive capitalism as described by Schumpeter, the promising capabilities of green capitalism were presented in detail. Nevertheless, the predominant criticism of capitalism scarcely assumes the Schumpeterian concept of 'creative destruction'. Rather, it focuses on a much later stage of evolution of the economic system, in which the socio-economic disparities as a result of economic, but also of other factors have manifested themselves distinctly and with great complexity (cf. trustified capitalism). The pure criticism of capitalism thus seems to us to be too superficial as an explanatory model, which relies on arguments that disregard precisely those fertile approaches to surmounting the energetic and environmental crisis that presently arise from numerous processes of creative destruction. The cradle-to-cradle approach illustrated above is only one example of a concept that, by means of innovation, abandons the old and establishes the new. Yet we also think that competition and the market alone will not suffice to concertedly solve the global environmental crisis. This calls for political action that, by creating suitable institutional frame conditions, succeeds in pooling society's forces with regard to the ecological questions of our time, thus specifically promoting innovation.

We demonstrated that the usefulness of state measures always also depends on the respective specific national and economic context. An objection to capitalist social orders in general disregards this diversity of contexts and is at risk 
of overlooking important determinants of crisis management. The decisive difference in the various capitalist systems' innovative strength lies in the degree to which the cooperation of the major market players - state, enterprises, science, and civil society - is institutionalised. This implies that a central part falls to the state in embedding the actions of the most important players into appropriate institutional structures. Only thereby will it be possible to shoulder the heavy load of material, costs, work, and coordination required for the energy system's transformation. A non-committal state runs the risk of failing this task. E.g., Solomon and Krishna (2011) showed that the intended transformation of the energy system in the USA after the oil crisis was unsuccessful due to the lack of suitable preconditions for innovation in niche markets. Moreover, Ćetković and Buzogány (2016) found that in liberal manifestations of capitalism, the deficiency of political and institutional instruments inhibits the necessary orchestration of activities on the part of state, industry, and financial sector. In sum, even though fossil fuels and the capitalist system based upon them have given rise to the environmental crisis, surmounting the crisis does not necessarily call for surmounting market-based approaches; rather, market economies based on regenerative energy systems that are competition-oriented and guided by state measures may develop great ecological and socio-economic effectivity.

\section{References}

Aitken, M., 2010. Why we still don't understand the social aspects of wind power: a critique of key assumptions within the literature. Energy Policy 38 (4), 1834-1841.

Alcott, B., 2005. Jevons' paradox. Ecol. Econ. 54 (1), 9-21.

Altvater, E., 2005. Das Ende des Kapitalismus wie wir ihn kennen. In: Eine radikale Kapitalismuskritik. Verlag Westfälisches Dampfboot, Münster.

Altvater, E., 2007. The social and natural environment of fossil capitalism. Socialist Register 43, 37-58.

Anagnostopoulos, J.S., Papantonis, D.E., 2008. Simulation and size optimization of a pumped-storage power plant for the recovery of wind-farms rejected energy. Renew. Energy 33, 1685-1694.

Andrews-Speed, P., 2012. The Governance of Energy in China - Transition to a Low-Carbon Economy. Palgrave Macmillan, New York.

Arentsen, M., Bellekom, S., 2014. Power to the people: local energy initiatives as seedbeds of innovation? Energy, Sustainability and Society 4 (2), 1-12.

Avila, S., 2018. Environmental justice and the expanding geography of wind power conflicts. Sustain. Sci. 13 (3), 599-616.

Baka, J., 2013. The political construction of wasteland: governmentality, land acquisition and social inequality in South India. Dev. Chang. 44 (2), 409-428.

Bathelt, H., Glückler, J., 2012. Wirtschaftsgeographie - Ökonomische Beziehungen in räumlicher Perspektive. UTB, Stuttgart.

Benson, S.M., Orr, F.M., 2008. Carbon dioxide capture and storage. Mater. Res. Soc. Bull. 33, 303-305.

Bettini, G., Karaliotas, L., 2013. Exploring the limits of peak oil: naturalising the political, de-politicising energy. Geogr. J. 179 (4), 331-341.

Blaschke, T., Biberacher, M., Gadocha, S., Schardinger, I., 2013. 'Energy landscapes': meeting energy demands and human aspirations. Biomass Bioenergy 55, 3-16.

Böhm, S., Misoczky, M.C., Moog, S., 2012. Greening capitalism? A Marxist critique of carbon markets. Organ. Stud. 33 (11), 1617-1638.

Bradley, K., Hedrén, J., 2014. Utopian thought in the making of green futures. In: Bradley, K., Hedrén, J. (Eds.), Green Utopianism: Perspectives, Politics and Micro-Practices. Routledge, New York, Oxon, pp. 1-20.

Brand, U., 2016. Green economy, green capitalism and the imperial mode of living: limits to a prominent strategy, contours of a possible new capitalist formation. Fudan Journal of the Humanities and Social Sciences 9 (1), 107-121.

Bridge, G., 2010. Geographies of peak oil: the other carbon problem. Geoforum 41 (4), 523-530.

Bridge, G., Bouzarovski, S., Bradshaw, M., Eyre, N., 2013. Geographies of energy tran- sition: space, place and the low-carbon economy. Energy Policy 53, 331-340.

Buch-Hansen, H., 2018. The prerequisites for a degrowth paradigm shift: insights from critical political economy. Ecol. Econ. 146, 157-163. 
Bulkeley, H., Watson, M., Hudson, R., Weaver, P., 2005. Governing municipal waste: towards a new analytical framework. J. Environ. Policy Plan. 7 (1), 1-24.

Bürer, M.J., Wüstenhagen, R., 2009. Which renewable energy policy is a venture capi- talist's best friend? Empirical evidence from a survey of international cleantech in- vestors. Energy Policy 37 (12), 4997-5006.

Castree, N., 2010. Crisis, continuity and change: neoliberalism, the left and the future of capitalism. Antipode 41 (S1), 185-213.

Ćetković, S., Buzogány, A., 2016. Varieties of capitalism and clean energy transitions in the European Union: when renewable energy hits different economic logics. Climaty Policy 16 (5), 642-657.

Chisholm, M., 1990. The increasing separation of production and consumption. In: Turner, B.L., Clark, W.C., Kates, R.W., Richards, J.F., Mathews, J.T., Meyer, W.B. (Eds.), The Earth as Transformed by Human Action. Global and Regional Changes in the Biosphere over the Past 300 Years. Cambridge University Press, Cambridge, pp. 87-102.

Cowell, R., 2010. Wind power, landscape and strategic, spatial planning - the construc- tion of 'acceptable locations' in Wales. Land Use Policy 27, 222-232.

Daly, H.E., 1991. Steady-State Economics, Second edition. Island Press, Washington. Daly, H.E., 1995. On

Nicholas Georgescu-Roegen's contributions to economics: an obituary essay. Ecol. Econ. 13, 149-154.

Daly, H.E., 2005. Economics in a full world. Sci. Am. 293, 100-107.

Demeritt, D., 2001. Scientific forest conservation and the statistical picturing of nature's limits in the progressive era United States. Society and Space 19, 431-459.

Devine-Wright, P., 2005. Beyond NIMBYism: towards and integrated framework for un- derstanding public perceptions of wind energy. Wind Energy 8, 125-139.

Ebeling, W., Freund, J., Schweitzer, F., 1998. Komplexe Strukturen: Entropie Und Information. B.T. Teubner Verlagsgesellschaft, Leipzig.

Ellis, G., Barry, J., Robinson, C., 2007. Many ways to say 'no', different ways to say 'yes': applying Q-methodology to understand public acceptance of wind farm proposals. J. Environ. Plan. Manag. 50 (4), 517-551.

Embshoff, D., Giegold, S., 2008. Solidarische Ökonomie im globalisierten Kapitalismus. VSA Verlag, Hamburg.

European Commission (EC), 2018. 2050 low-carbon economy. https://ec.europa.eu/ clima/policies/strategies/2050_en. (accessed 28 September 2018).

Fares, R., 2015. Renewable Energy Intermittency Explained: Challenges, Solutions, and Opportunities. https://blogs.scientificamerican.com/plugged-in/renewable-energy- intermittency-explained-challengessolutions-and-opportunities/ (accessed 8 August 2017).

Gailing, L., Hüesker, F., Kern, K., Röhring, A., 2013. Die räumliche Gestaltung der Energiewende zwischen Zentralität und Dezentralität. Explorative Anwendung einer Forschungsheuristik. https://leibnizirs.de/fileadmin/user_upload/IRS_Working_Paper/wp_energiewende_raum_zentral_dezentral.pdf, Accessed date: 11 April 2018.

Garcia-Olivares, A., Sole, J., 2015. End of growth and the structural instability of capit- alism - from capitalism to a symbiotic economy. Futures $68,31-43$.

Gawel, E., Strunz, S., Lehmann, P., 2012. The German Energiewende under Attack: Is there an Irrational Sonderweg? https://www.econstor.eu/bitstream/10419/64555/ 1/726590568.pdf, Accessed date: 15 March 2018.

Geels, F.W., 2011. The multi-level perspective on sustainability transitions: responses to seven criticisms. Environmental Innovation and Societal Transitions 1 (1), 24-40.

Georgescu-Roegen, N., 1971. The Entropy Law and the Economic Process. Harvard University Press, Harvard. Georgescu-Roegen, N., 1986. The entropy law and the economic process in retrospect. East. Econ. J. 7 (1), 3-25.

German Aerospace Center (DLR), 2006. Trans-Mediterranean Interconnection for Concentrating Solar Power. https://www.dlr.de/tt/Portaldata/41/Resources/ dokumente/institut/system/projects/WP00_TRANS-CSPIntroduction_and_Summary-Final.pdf, Accessed date: 10 October 2018.

German Aerospace Center (DLR), 2007. Concentrating Solar Power for Seawater Desalination. http://www.dlr.de/tt/Portaldata/41/Resources/dokumente/institut/ system/projects/aqua-csp/AQUA-CSPFull-Report-Final.pdf, Accessed date: 8 June 2018.

Grossmann, W.D., Grossmann, I., Steininger, K.W., 2014. Solar electricity generation across large geographic 
areas. Part II: a Pan-American energy system based on solar. Renew. Sust. Energ. Rev. 32, 983-993.

Gugler $\mathrm{GmbH}$, 2018. Cradle to Cradle Druckprodukte: Innovation aus Österreich. https:// www.gugler.at/print/nachhaltigkeit/cradle-to-cradletm-druckprodukte-innovation-aus-oesterreich.html, Accessed date: 25 October 2018.

Hadjipaschalis, I., Poullikkas, A., Efthimiou, V., 2009. Overview of current and future energy storage technologies for electric power applications. Renew. Sust. Energ. Rev. 13, 1513-1522.

Harris, J., 2010. Going green to stay in the black: transnational capitalism and renewable energy. Race \& Class 52 (2), 62-78.

Harris, J., 2013. Can green capitalism build a sustainable society? International Critical Thought 3 (4), 468479.

Harriss-White, B., Harriss, E., 2007. Unsustainable capitalism: the politics of renewable energy in the UK. Social Register 43, 72-101.

Harvey, D., 1996. Justice, Nature and the Geography of Difference. Blackwell Publishers Ltd, Oxford.

Harvey, D., 2011. Roepke lecture in economic geography - crises, geographic disruptions and the uneven development of political responses. Econ. Geogr. 8, 1-22.

Herzog, L., Honneth, A. (Eds.), 2016. Joseph A. Schumpeter - Schriften zur Ökonomie und Soziologie. Suhrkamp Verlag, Berlin.

Hildyard, N., Hegde, P., Wolvekamp, P., Reddy, S., 2001. Pluralism, participation and power: Joint forest management in India. In: Cooke, B., Kothari, U. (Eds.), Participation: The New Tyranny? Zed Books, London, New York, pp. 56-71.

Huber, M.T., 2009. Energizing historical materialism: fossil fuels, space and the capitalist mode of production. Geoforum 40 (1), 105-115.

Huber, M.T., 2013. Fueling capitalism: oil, the regulation approach, and the ecology of capital. Econ. Geogr. 89 (2), 171-194.

Iversen, T., 2005. Capitalism, Democracy, and Welfare. Cambridge University Press, Cambridge.

Jänicke, M., 2007. Trendsetter im "regulativen Kapitalismus": Das Beispiel umweltpoli- tischer Pionierländer. In: Holzinger, K., Jörgens, H., Knill, C. (Eds.), Transfer, Diffusion und Konvergenz von Politiken. Springer Verlag, Heidelberg, pp. 131-149.

Jensen, S.H., Larsen, P.H., Mogensen, M., 2007. Hydrogen and synthetic fuel production from renewable energy sources. Int. J. Hydrog. Energy 32 (15), 3253-3257.

Johnstone, N., Haščič, I., Popp, D., 2010. Renewable energy policies and technological innovation: evidence based on patent counts. Environ. Resour. Econ. 45 (1), 133-135.

Kaberger, T., Mansson, B., 2001. Entropy and economic processes - physics perspectives. Ecol. Econ. 36 (1), 165-179.

Kallis, G., 2011. In defence of degrowth. Ecol. Econ. 70 (5), 873-880.

Kallis, G., Martinez-Alier, J., Norgaard, R.B., 2009. Paper assets, real debts: an ecological- economic exploration of the global economic crisis. Crit. Perspect. Int. Bus. 5 (1-2), 14-25.

Kenis, A., Lievens, M., 2016. Greening the economy or economizing the green project? When environmental concerns are turned into a means to save the market. Review of Radical Political Economics 48 (2), 217234.

Kinder, J., 2016. The coming transition: fossil capital and our energy future. Social. Democr. $30(2), 8-27$.

Kranert, M., Cord-Landwehr, K., 2010. Einführung in die Abfallwirtschaft. Springer Verlag, Heidelberg.

Kungl, G., 2015. Stewards or sticklers for change? Incumbent energy providers and the politics of the German energy transition. Energy Res. Soc. Sci. 8, 13-23.

Lauber, V., Jacobsson, S., 2016. The politics and economics of constructing, contesting and restricting sociopolitical space for renewables - the German renewable energy act. Environmental Innovation and Societal Transitions 18, 147-163.

Levien, M., 2013. Regimes of dispossession: from steel towns to special economic zones. Dev. Chang. 44 (2), 381-407.

Liljenfeldt, J., 2015. Legitimacy and efficiency in planning processes - (how) does wind power change the situation? Eur. Plan. Stud. 23 (4), 811-827.

Marques, P., 2008. Localised technological change: towards the economics of complexity. 
J. Econ. Geogr. 9 (2), 288-290.

Martinez-Alier, J., 1987. Ecological economics: energy, environment and society.

Blackwell Publishers Ltd, Oxford.

Martinez-Alier, J., 2012. Environmental justice and economic degrowth: an alliance be- tween two movements.

Capital. Nat. Social. 23 (1), 51-73.

Matek, B., Gawell, K., 2015. The benefits of baseload renewables: a misunderstood energy technology. Electr. J. 28 (2), 101-112.

Mathews, J., 2011. Naturalizing capitalism: the next great transformation. Futures 43 (8), 868-879.

McCarthy, J., 2015. A socioecological fix to capitalist crisis and climate change? The possibilities and limits of renewable energy. Environ Plan A 47, 2485-2502.

McDonough, W., Braungart, M., 2013. The Upcycle: Beyond Sustainability - Designing for Abundance, Farrar. Straus and Giroux, New York.

Meadows, D.H., Meadows, D.L., Randers, J., Behrens, W.W., 1972. The Limits to Growth. A Report for the Club of Rome's Project on the Predicament of Mankind. Universe Books, New York.

Meadows, D.H., Randers, J., Meadows, D.L., 2004. The Limits to Growth - The 30-Year Update. Earthscan, London.

Midgley, P., 2011. Bicycle-Sharing Schemes: Enhancing Sustainable Mobility in Urban Areas. http://www.cleanairinstitute.org/cops/bd/file/tnm/13-bicycle-sharing.pdf, Accessed date: 9 March 2018.

Moore, J.W., 2016. Anthropocene or Capitolocene? Nature, History, and the Crisis of Capitalism. PM Press, Oakland.

Mulhall, D., Braungart, M., 2010. Cradle to Cradle. Criteria for the Built Environment. Duurzaam Gebouwd, Nunspeet.

Murdoch, J., 2000. Space against time: competing rationalities in planning for housing.

Trans. Inst. Br. Geogr. 25 (4), 503-519.

Murphy, D.J., Hall, C.A.S., 2011. Energy return on investment, peak oil, and the end of economic growth. Ann. N. Y. Acad. Sci. 1219 (1), 52-72.

Nasirov S., Agostini C., Silva M. C., Cáceres G., 2017. Renewable energy transition: a market-driven solution for the energy and environmental concerns in Chile. Clean Techn. Environ. Policy 20 (1), 3-12.

North, P., 2010. Eco-localization as a progressive response to peak oil and climate change - a sympathetic critique. Geoforum 41 (4), 585-594.

Osterhammel, J., 2011. Die Verwandlung der Welt. Eine Geschichte des 19. Jahrhunderts.

Verlag C.H. Beck, München.

Palensky, P., Dietrich, D., 2011. Demand side management: Demand response, intelligent energy systems, and smart loads. Transactions on Industrial Informatics 7 (3), 381-388.

Palmas C., Siewert A., V. Haaren C., 2015. Exploring the decision-space for renewable energy generation to enhance spatial efficiency. Environ. Impact Assess. Rev. 52, 9-17.

Polanyi, K., 1957. The Great Transformation. Beacon Press, Boston.

Polimeni, J.M., Mayumi, K., Giampietro, M., Alcott, B., 2015. The Myth of Resource Efficiency. The Jevons Paradox. Routledge, London.

Prettenthaler, F.E., Steininger, K.W., 1999. From ownership to service use lifestyle: the potential of car sharing. Ecol. Econ. 28 (3), 443-453.

Quaschning, V., 2014. Regenerative Energiesysteme. Technologien, Berechnung, Simulation. Carl Hanser Verlag, München.

Ramchurn, S.D., Vytelingum, P., Rogers, A., Jennings, N., 2011. Agent-based control for decentralised demand side management in the smart grid 10, 5-12. https://eprints. soton.ac.uk/271985/2/ userfiles.soton.ac.uk_Users_nsc_mydesktop_271985ramchurn.pdf (accessed 16 April 2018).

Raven, R., Kern, F., Verhees, B., Smith, A., 2016. Niche construction and empowerment through socio-political work. A meta-analysis of six low-carbon technology cases. Environmental Innovations and Societal Transitions 18, 164-180.

Resch, G., Held, A., Faber, T., Panzer, C., Toro, F., Haas, R., 2008. Potentials and pro- spects for renewable energies at global scale. Energy Policy 36 (11), 4048-4056.

Rifkin, J., 2013. The Third Industrial Revolution. How Lateral Power Is Transforming Energy, the Economy, and 
the World. Pallgrave Macmillan, Basingstoke.

Sarkar, S., Kern, B., 2008. Ökosozialismus oder Barbarei. Eine zeitgemäße Kapitalismuskritik. https://kritisches-netzwerk.de/forum/oekosozialismus-oder- barbarei-eine-zeitgemaessekapitalismuskritik (accessed 23 May 2018).

Schmid, A., 2016. Neue Kontakte sorgen für Wirkungsgrad-Sprung bei Solarzellen. http:// www.wiwo.de/technologie/green/tech/photovoltaik-neue-kontakte-sorgen-fuer- wirkungsgrad-sprungbei-solarzellen/14639792.html (accessed 8 January 2018).

Schöbel, S., 2012. Windenergie und Landschaftsästhetik - Zur landschaftsgerechten Anordnung von Windfarmen. Jovis, Berlin.

Schumpeter, J.A., 1994. History of Economic Analysis. Oxford University Press, New York.

Schumpeter, J.A., 2009. Can Capitalism Survive? Creative Destruction and the Future of the Global Economy. Harper Perennial, New York.

Schwartzman, D., 2008. The limits to entropy: continuing misuse of thermodynamics in environmental and Marxist theory. Science and Society 72 (1), 43-62.

Shove, E., 1998. Gaps, barriers and conceptual chasms: theories of technology transfer and energy in buildings. Energy Policy 26 (15), 1105-1112.

Sieferle, R.P., 1997. Rückblick auf die Natur. Eine Geschichte des Menschen und seiner Umwelt. Luchterhand Verlag, München.

Sieferle, R.P., 2001. The Subterranean Forest. Energy Systems and the Industrial Revolution. The White Horse Press, Cambridgeshire.

Solomon, B.D., Krishna, K., 2011. The coming sustainable energy transition: history, strategies, and outlook. Energy Policy 39 (11), 7422-7431.

Statista, 2017. Prognostizierte statische Reichweite von Ressourcen. https://de.statista. com/statistik/daten/studie/152334/umfrage/statische-reichweite-von-ressourcen/, Accessed date: 27 September 2018.

Stenzel, T., Frenzel, A., 2008. Regulating technological change - the strategic reactions of utility companies towards subsidy policies in the German, Spanish and UK electricity markets. Energy Policy 36, 2645-2657.

Sturm, B., Vogt, C., 2011. Marktversagen durch externe Effekte. In: Strum, B., Vogt, C. (Eds.), Umweltökonomik Eine anwendungsorientierte Einführung. Springer Verlag, Heidelberg, pp. 17-40.

Swyngedouw, E., 2010. Apocalypse forever? Post-political populism and the spectre of climate change. Theory, Culture \& Society $27(2-3), 213-232$.

Van d. Horst, D., 2007. NIMBY or not? Exploring the relevance of location and the politics of voiced opinions in renewable energy siting controversies. Energy Policy 35 (5), 2705-2714.

Van den Bergh, J.C.J.M., 2011. Environment versus growth - a criticism of "degrowth" and a plea for "a-growth". Ecol. Econ. 70 (5), 881-890.

Walsh, P.R., 2012. Innovation Nirvana or Innovation Wasteland? Identifying commer- cialization strategies for small and medium renewable energy enterprises. Technovation 32 (1), 32-42.

Walter, K., Bosch, S., 2013. Intercontinental cross-linking of power supply - calculating an optimal power line corridor from North Africa to Central Europe. Energy, Sustainability and Society 3 (7). https://doi.org/10.1186/2192-0567-3-14.

Walter, G., Gutscher, H., 2013. Generelle Befürwortung von Windkraftanlagen vor Ort vs. Befürwortung spezifischer Windkraftprojekte: Der Einfluss von Projekt- und Verfahrensparametern. Umweltpsychologie 17 (2), 124-144.

Wangler, L.U., 2013. Renewables and innovation: did policy induced structural change in the energy sector effect innovation in green technologies? J. Environ. Plan. Manag. 56 (2), 211-237.

Yenneti, K., Day, R., Golubchikov, O., 2016. Spatial justice and the land politics of re- newables: dispossessing vulnerable communities through solar energy mega-projects. Geoforum 76, 90-99.

Yildiz, Ö., Rommel, J., Debor, S., Holstenkamp, L., Mey, F., Müller, J.R., Radtke, J., Rognli, J., 2015. Renewable energy cooperatives as gatekeepers or facilitators? Recent developments in Germany and a multidisciplinary research agenda. Energy Res. Soc. Sci. 6, 59-73.

Zoellner, J., Schweizer-Ries, P., Wemheuer, C., 2008. Public acceptance of renewable energies: results from case studies in Germany. Energy Policy 36 (11), 4136-4141. 